\title{
Kesalahan Siswa Sekolah Menengah Pertama dalam Menyelesaikan Soal Matematika Tipe Pisa
}

\author{
Jihan Della Safegi ${ }^{1}$, Hapizah $^{2 *}$, Cecil Hiltrimartin ${ }^{3}$, Made Sukaryawan ${ }^{4}$, Kodri Madang ${ }^{5}$, \\ Ketang Wiyono ${ }^{6}$, Yenny Anwar ${ }^{7}$ \\ 1,2,3Pendidikan Matematika, Universitas Sriwijaya, Indonesia \\ ${ }^{4}$ Pendidikan Kimia, Universitas Sriwijaya, Indonesia \\ ${ }^{5,7}$ Pendidikan Biologi, Universitas Sriwijaya, Indonesia \\ ${ }^{6}$ Pendidikan Fisika, Universitas Sriwijaya, Indonesia \\ *hapizah@fkip.unsri.ac.id
}

\begin{abstract}
Abstrak
Penelitian ini bertujuan untuk mengetahui bentuk kesalahan siswa dan faktor yang menyebabkan siswa melakukan kesalahan dalam menyelesaikan soal matematika tipe PISA. Analisis kesalahan dilakukan berdasarkan analisis newman melalui tes dan wawancara. Penelitian ini dilaksanakan di salah satu SMP di Provinsi Kepulauan Bangka Belitung dengan melibatkan 26 siswa. Subjek dipilih berdasarkan teknik purposive sampling dengan 3 pertimbangan yaitu kemampuan akademik, rekomendasi guru dan kesediaan siswa. Penelitian ini menggunakan metode deskriptif kualitatif. Soal tes matematika PISA yang diujikan terdiri konten change and relationship, space and shape, quantity dan uncertain and data.. Hasilnya menunjukkan bahwa kesalahan membaca sebesar 40,21\%,kesalahan pemahaman sebesar $41,86 \%$, kesalahan transformasi sebesar $87,29 \%$, kesalahan keterampilan proses sebesar 90,26\% dan kesalahan penulisan jawaban sebesar $88,46 \%$. Sedangkan uncertain and data merupakan konten dengan persentase kesalahan terbesar yaitu $82,31 \%$. Secara umum kesalahan disebabkan oleh siswa yang tidak bisa mengaitkan soal PISA dengan materi yang biasa dipelajarinya dan siswa tidak terbiasa mengerjakan soal PISA.
\end{abstract}

Kata kunci: Analisis Newman, Kesalahan Siswa, PISA.

\begin{abstract}
This study aimed to determine student errors and the factors that caused students to make mistakes in solving PISA-type math problems. Error analysis was carried out based on Newman's analysis through tests and interviews. This research was conducted in one of the junior high schools in the Province of the Bangka Belitung Islands, involving 26 students. Subjects were selected based on a purposive sampling technique with three considerations: academic ability, teacher recommendations, and student willingness. This study used the descriptive qualitative method. The PISA math test questions tested consisted of change and relationship, space and shape, quantity and uncertainty, and data content. The results showed that reading errors were $40.21 \%$, comprehension errors were $41.86 \%$, transformation errors were $87.29 \%$, process skill error is $90.26 \%$, and the answer writing error is $88.46 \%$. While uncertain and data is the content with the most significant error percentage, which is $82.31 \%$. In general, errors were caused by students who cannot relate PISA questions to the material they usually study, and students were not accustomed to working on PISA questions.
\end{abstract}

Keywords: Newman Analysis, Student Mistake, PISA.

Received: April 07, 2021/ Accepted: Juli 26, 2021/ Published Online: Juli 29, 2021 


\section{PENDAHULUAN}

Matematika merupakan salah satu ilmu yang penting untuk diajarkan kepada siswa untuk meningkatkan dan mengembangkan kualitas sumber daya manusia.Menurut Cokcroft (Mahmudah, 2018), matematika perlu diajarkan kepada siswa karena (1) selalu digunakan dalam segi kehidupan, (2) semua bidang studi memerlukan keterampilan matematika yang sesuai, (3) merupakan sarana komunikasi yang kuat, singkat dan jelas, (4) dapat digunakan untuk menyajikan informasi dalam berbagai cara, (5) meningkatkan kemampuan berpikir logis, ketelitian, dan kesadaran keruangan, dan (6) memberikan kepuasan terhadap usaha memecahkan masalah yang menantang.

Keikutsertaan Indonesia dalam kompetensi global secara internasional merupakan salah satu hal yang dapat mengukur kemampuan siswa di Negara Indonesia ketika bersaing secara global. PISA adalah kompetensi internasional yang menilai kemampuan dan keterampilan membaca, matematika dan sains siswa dengan pendekatan literasi (OECD, 2019). Menurut OECD (2019), perlunya kompetensi global ini dilakukan karena (1) untuk hidup harmonis di masyarakat multikulturalisme, (2) untuk berkembang dalam perubahan pasar tenaga kerja, (3) untuk mengggunakan platform media secara efektif dan bertanggung jawab, serta (4) untuk mendukung pembangunan berkelanjutan. Pentingnya siswa di Indonesia untuk mengerjakan dan mempelajari soal-soal tipe PISA menurut Putra $\underline{(2018)}$ karena hasil survei PISA dijadikan alasan bagi Kemendikbud untuk merevisi kurikulum KTSP menjadi kurikulum 2013.

Menurunnya pencapaian skor PISA matematika Negara Indonesia menunjukkan adanya kesulitan siswa Indonesia dalam menyelesaikan soal matematika PISA. Indonesia berada pada peringkat 7 dari bawah yakni pada posisi 73 dengan skor rata-rata 379 berada diatas Arab Saudi dengan skor 373 (OECD, 2019). Menurut hasil yang dikeluarkan oleh OECD (2019), skor matematika Negara Indonesia pada tahun 2015 sebesar 386 dan pada tahun 2018 sebesar 379, skor ini berada sangat jauh dari rata-rata OECD yaitu sebesar 489.

Menurut Wati \& Murtiyasa (2016), rendahnya prestasi tersebut tidak terlepas dari proses pembelajaran di sekolah, salah satunya siswa belum terbiasa menyelesaikan soal-soal dengan karakteristik konteks nyata dan hanya mengerjakan soal-soal yang dicontohkan guru tanpa mengetahui manfaatnya dalam kehidupan sehari-hari serta kesulitan siswa dalam menyelesaikan soal tersebut dapat terjadi disebabkan oleh adanya kesalahan, banyaknya kesalahan yang dilakukan siswa dalam mengerjakan soal bisa menjadi petunjuk sejauh mana penguasaan siswa terhadap suatu materi (Utami, 2017). 
Sesuai dengan yang dikatakan oleh Fatimah (2018), langkah dan upaya yang tepat untuk memecahkan masalah ini ialah dengan mengetahui bentuk kesalahan yang dilakukan siswa dalam menyelesaikan soal matematika tipe PISA. Selain bentuk kesalahan, faktor yang menyebabkan siswa melakukan kesalahan tersebut juga penting untuk diketahui untuk meminimalisir kesalahan yang terjadi. Hal ini bertujuan agar ditemukannya solusi sehingga guru-guru bisa mengatasi kesalahan tersebut serta untuk siswa agar bisa memperbaiki dan tidak mengulangi kesalahan yang sama di masa yang akan datang (Astuty \&Wijayanti, 2013 ; Siswandi \& Sujadi 2016; Umam, 2014). Proses di atas biasanya disebut dengan analisis kesalahan. Salah satu cara untuk menganalisis kesalahan yang dilakukan siswa dalam menyelesaikan soal matematika adalah teori Newman (Susilowati \& Ratu, 2018). Menurut Newman (Clement, 1980), terdapat 5 tipe kesalahan yang dilakukan siswa dalam mengerjakan soal matematika, yaitu (1) reading error, (2) comprehension error, (3) transformation error, (4) processing skill error, dan (5) encoding error.

Adapun ciri khas soal matematika tipe PISA yaitu soal cerita yang bertujuan untuk menilai kemampuan literasi matematis dan sains siswa. Maka, menurut Putri \& Mega (2017), teori Newman merupakan teori analisis kesalahan yang tepat untuk digunakan. Dikarenakan dalam menyelesaikan soal cerita dibutuhkan kemampuan membaca yang berhubungan dengan keterampilan berpikir siswa. termasuk didalamnya ialah soal-soal tipe PISA.

Ada beberapa penelitian sebelumnya yang membahas tentang analisis kesalahan siswa dalam menyelesaikan soal matematika tipe PISA namun hanya dari salah satu kontennya saja seperti hanya Change and Relationship, Quantity, Space and Shape atau Uncertain and Data saja. Oleh karena itu disini peneliti ingin melakukan penelitian tentang analisis kesalahan siswa dalam menyelesaikan soal matematika tipe PISA dari keseluruhan konten. Sesuai dengan teori analisis kesalahan yang ingin peneliti gunakan yaitu teori Newman, peneliti akan melakukan analisis berdasarkan tahapan Newman namun akan di bahas lebih dalam lagi dengan penjabaran dari indikator-indikator yang telah di tuliskan oleh Newman.

Oleh karena itu, berdasarkan penjelasan di atas maka peneliti tertarik untuk melakukan penelitian dengan judul "Analisis Kesalahan Siswa dalam menyelesaikan Soal Matematika Tipe PISA di Sekolah Menengah Pertama (SMP)".

\section{METODE}

Penelitian ini merupakan penelitian dekriptif kualitatif dengan subjek sebanyak 26 siswa yang terdiri atas 8 siswa laki-laki dan 18 siswa perempuan di salah satu SMP di Provinsi Bangka Belitung. Subjek dipilih berdasarkan teknik purposive sampling (Sugiyono, 
2015) dengan 3 pertimbangan yaitu kemampuan akademik, rekomendasi guru dan kesediaan siswa.

Adapun fokus penelitian ini adalah kesalahan siswa dalam menyelesaikan soal matematika tipe PISA di Sekolah Menengah Pertama (SMP). Kesalahan siswa ini dianalisis menggunakan metode Newman, adapun indikator kesalahan dari metode Newman ini tersaji dalam Tabel 1 berikut

Tabel 1. Indikator Kesalahan Newman

\begin{tabular}{|c|c|c|}
\hline No & Tahapan dalam Analisis Newman & Indikator Kesalahan \\
\hline 1. & Membaca (Reading) & $\begin{array}{l}\text { - Salah menuliskan angka yang } \\
\text { diketahui dalam soal } \\
\text { - Salah dalam menuliskan tanda } \\
\text { operasi hitung yang ada pada soal }\end{array}$ \\
\hline & Pemahaman (Comprehension) & $\begin{array}{l}\text { Tidak dapat menafsirkan yang } \\
\text { diketahui dari soal } \\
\text { - } \quad \text { Tidak dapat menafsirkan yang } \\
\text { ditanya dalam soal } \\
\text { - Salah menafsirkan yang diketahui } \\
\text { dalam soal } \\
\text { - Salah menafsirkan yang ditanya } \\
\text { dalam soal } \\
\text { - Salah dalam } \\
\text { memilih/menggunakan data yang } \\
\text { relevan dari soal }\end{array}$ \\
\hline & Transformasi (Transformation) & 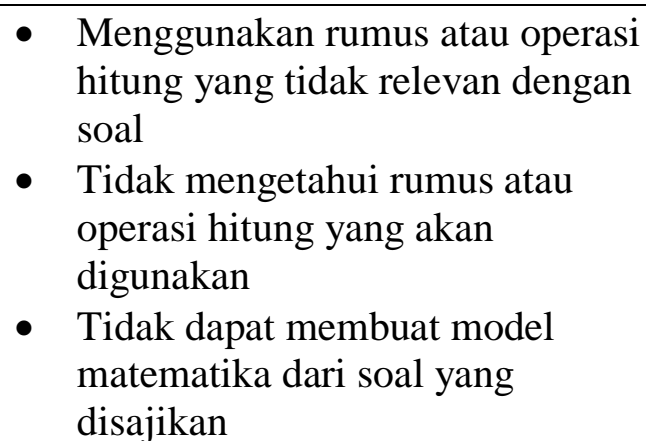 \\
\hline & $\begin{array}{l}\text { Keterampilan Proses (Processing } \\
\text { Skill) }\end{array}$ & $\begin{array}{l}\text { - Tidak bisa menentukan prosedur } \\
\text { atau langkah-langkah yang } \\
\text { digunakan } \\
\text { - Kesalahan dalam komputasi } \\
\text { - Tidak dapat melanjutkan prosedur } \\
\text { penyelesaian } \\
\text { - Tidak dapat menjelaskan proses } \\
\text { komputasi dalam lembar jawaban }\end{array}$ \\
\hline & Penulisan Jawaban (Encoding) & $\begin{array}{l}\text { - Salah perhitungan pada jawaban } \\
\text { akhir } \\
\text { - Tidak dapat menentukan dan } \\
\text { menuliskan jawaban akhir }\end{array}$ \\
\hline
\end{tabular}




\begin{tabular}{lll}
\hline No & Tahapan dalam Analisis Newman & \multicolumn{1}{c}{ Indikator Kesalahan } \\
\hline & $\bullet$ & Menuliskan jawaban yang tidak \\
& & tepat \\
& $\bullet$ & Tidak menuliskan satuan yang \\
& & sesuai \\
& $\bullet$ & Salah dalam menuliskan \\
& notasi/simbol matematika \\
\hline
\end{tabular}

Teknik pengumpulan data dilakukan dengan dua cara yaitu tes dan wawancara. Pengambilan data tes dilakukan melalui 3 kali pertemuan, dengan rincian 2 pertemuan untuk mengenalkan PISA dan cara menyelesaikan contoh soal PISA matematika serta satu pertemuan untuk tes. Soal tes terdiri dari 8 soal uraian yang telah di validasi yaitu 2 soal untuk tiap masing-masing konten (Change and Relationship, Space and Shape, Quantity dan Uncertain and Data). Hasil tes siswa kemudian akan dianalisis menggunakan analisis Newman lalu dipilih 5 orang siswa untuk dilakukan wawancara. 5 orang siswa yang di wawancara dipilih berdasarkan hasil tes siswa yang tertinggi, sedang dan rendah.

\section{HASIL PENELITIAN}

Penelitian ini terdiri dari tiga tahapan yaitu tahapan persiapan penelitian, tahapan pelaksanaan penelitian dan tahapan analisis data. Pada tahap persiapan peneliti melakukan observasi ke sekolah dan melakukan pemiliihan subjek penelitian serta menyusun dan memvalidasi instrumen penelitian. Instrumen tes berupa soal PISA yang terdiri dari konten Change and Relationship, Space and Shape, Quantity dan Uncertain and Data di ambil dari soal matematika PISA 2012 yang telah diterjemahkan peneliti kedalam bahasa Indonesia beserta rubrik penskoran dan pedoman wawancara.

Pada tahap pelaksanaan penelitian dilakukan selama 3 kali pertemuan dan 1 hari untuk wawancara. 3 kali pertemuan dikelas dilaksanakan pada tanggal 5-7 Oktober 2020 dan wawancara dilaksanakan pada 22 Oktober 2020. Rincian pelaksanaan pertemuan dikelas yaitu 2 kali petemuan untuk pengenalan PISA dan cara menyelesaikan soal PISA serta 1 pertemuan untuk tes.

Berdasarkan hasil analisis jawaban hasil tes, hampir semua siswa melakukan tiap jenis kesalahan dari setiap soal. Tabel 2 berikut menunjukkan persentase kesalahan yang dilakukan oleh siswa. 
Tabel 2. Persentase Kesalahan Siswa Berdasarkan Indikator Kesalahan Newman

\begin{tabular}{|c|c|c|c|c|c|c|c|c|c|c|}
\hline \multirow{2}{*}{$\begin{array}{c}\text { Jenis } \\
\text { Kesalahan }\end{array}$} & \multirow{2}{*}{$\begin{array}{c}\text { Jumlah B } \\
\text { dan S }\end{array}$} & \multicolumn{8}{|c|}{ No Soal } & \multirow{2}{*}{ Total } \\
\hline & & 1 & 2 & 3 & 4 & 5 & 6 & 7 & 8 & \\
\hline \multirow{5}{*}{ Membaca } & B & 56 & 47 & 20 & 39 & 63 & 51 & 36 & 30 & 342 \\
\hline & $\mathrm{S}$ & 22 & 31 & 6 & 39 & 15 & 27 & 42 & 48 & 230 \\
\hline & $B+S$ & 78 & 78 & 26 & 78 & 78 & 78 & 78 & 78 & 572 \\
\hline & Persentase & 28,21 & 39,7 & 23. & 50 & 19 , & 36 , & 53 , & 61 , & 40,21 \\
\hline & Kesalahan & $\%$ & $\%$ & $\begin{array}{l}08 \\
\%\end{array}$ & $\%$ & $\begin{array}{l}23 \\
\%\end{array}$ & $\begin{array}{l}42 \\
\%\end{array}$ & $\begin{array}{l}85 \\
\%\end{array}$ & $\begin{array}{l}54 \\
\%\end{array}$ & $\%$ \\
\hline \multirow{5}{*}{$\begin{array}{c}\text { Pemaham } \\
\text { an }\end{array}$} & B & 56 & 44 & 20 & 39 & 63 & 48 & 33 & 30 & 333 \\
\hline & $\mathrm{S}$ & 22 & 34 & 6 & 39 & 15 & 30 & 45 & 48 & 239 \\
\hline & $B+S$ & 78 & 78 & 26 & 78 & 78 & 78 & 78 & 78 & 572 \\
\hline & Persentase & 28,21 & 43,59 & 23 & 50 & 19 & 38 , & 57 & 61, & 41,78 \\
\hline & Kesalahan & $\%$ & $\%$ & $\begin{array}{l}08 \\
\%\end{array}$ & $\%$ & $\begin{array}{l}23 \\
\%\end{array}$ & $\begin{array}{l}46 \\
\%\end{array}$ & $\begin{array}{l}69 \\
\%\end{array}$ & $\begin{array}{l}54 \\
\%\end{array}$ & $\%$ \\
\hline \multirow{5}{*}{$\begin{array}{c}\text { Transform } \\
\text { asi }\end{array}$} & B & 15 & 0 & 16 & 0 & 21 & 21 & 0 & 3 & 76 \\
\hline & S & 63 & 78 & 36 & 78 & 57 & 57 & 75 & 75 & 522 \\
\hline & $B+S$ & 78 & 78 & 52 & 78 & 78 & 78 & 78 & 78 & 598 \\
\hline & Persentase & 80,77 & 100 & 69, & 100 & 73 & 73 , & 100 & 96 , & 87,29 \\
\hline & Kesalahan & $\%$ & $\%$ & $\begin{array}{l}23 \\
\%\end{array}$ & $\%$ & $\begin{array}{l}08 \\
\%\end{array}$ & $\begin{array}{l}08 \\
\%\end{array}$ & $\%$ & $\begin{array}{l}15 \\
\%\end{array}$ & $\%$ \\
\hline \multirow{6}{*}{ Proses } & B & 24 & 0 & 16 & 4 & 28 & 0 & 0 & 4 & 76 \\
\hline & S & 80 & 104 & 36 & 100 & 76 & $\begin{array}{c}10 \\
4\end{array}$ & 104 & $\begin{array}{c}10 \\
0\end{array}$ & 704 \\
\hline & $\mathrm{B}+\mathrm{S}$ & 104 & 104 & 104 & 52 & 104 & 10 & 104 & 10 & 780 \\
\hline & $D+2$ & 104 & 104 & 104 & 32 & 104 & 4 & 104 & 4 & 100 \\
\hline & Persentase & 76,92 & & 69, & 96 & 73, & 10 & 100 & 96 , & 90,26 \\
\hline & Kesalahan & $\%$ & $100 \%$ & $\begin{array}{l}23 \\
\%\end{array}$ & $\begin{array}{l}15 \\
\%\end{array}$ & $\begin{array}{l}08 \\
\%\end{array}$ & $0 \%$ & $\%$ & 15 & $\%$ \\
\hline \multirow{5}{*}{$\begin{array}{l}\text { Penulisan } \\
\text { Jawaban }\end{array}$} & B & 10 & 2 & 12 & 0 & 22 & 0 & 0 & 2 & 48 \\
\hline & S & 42 & 50 & 40 & 52 & 30 & 52 & 52 & 50 & 368 \\
\hline & $B+S$ & 52 & 52 & 52 & 52 & 52 & 52 & 52 & 52 & 416 \\
\hline & Persentase & 80,77 & 96,15 & 76 & 100 & 57 , & 10 & 100 & 96, & 88,46 \\
\hline & Kesalahan & $\%$ & $\%$ & $9 \%$ & $\%$ & $\begin{array}{l}69 \\
\%\end{array}$ & $\%$ & $\%$ & $\begin{array}{l}15 \\
\%\end{array}$ & $\%$ \\
\hline
\end{tabular}

\section{PEMBAHASAN}

\section{Kesalahan Membaca}

Kesalahan membaca yang dilakukan siswa adalah sebesar 40,21\%, kesalahan ini merupakan kesalahan dengan persentase paling kecil diantara semua bentuk kesalahan. Kesalahan membaca yang dilakukan siswa meliputi salah dalam menuliskan angka yang diketahui dalam soal dan salah dalam menuliskan tanda operasi hitung yang ada dalam soal. Dari hasil tes siswa, sebagian besar sudah tidak lagi melakukan kesalahan membaca walaupun 
baru pertama sekali menyelesaikan soal matematika PISA ini. Salah satu subjek yaitu RO yang tidak menjawab sama sekali pada soal nomor 5 menjadi salah satu narasumber wawancara peneliti untuk mengetahui sebab kesalahan membaca RO dalam menyelesaikan soal matematika PISA ini. Berikut adalah kutipan wawancara peneliti dengan subjek RO

Kutipan Wawancara

$P \quad$ : "Coba kamu baca soal nomor 5 ini, kalau ada kata-kata yang tidak dimengerti silahkan tinggalkan atau tidak usah dibaca ya"

$R O$ : "Oke bu" (membaca soal sampai selesai tanpa ada yang ditinggalkan)

$P \quad:$ "Ada kata-kata yang tidak kamu mengerti dari soal? "

RO :"Tidak bu"

$P \quad$ : "Bisa menuliskan ini ?" (sambil menunjuk kesalah satu angka dari dalam soal)

RO : "Bisa bu"

$P \quad$ : "Coba tuliskan"

RO : "Baik bu” (menuliskan angkanya dengan benar)

$P \quad$ : "Sekarang apalagi yang harus kita lakukan untuk menjawab soal ini ?"

RO : "Menuliskan yang diketahui dan ditanya dari soal bu"

$P$ : "Iya benar, coba tuliskan apa yang diketahuinya"

$R O$ :"Tidak tau bu, gimana nulisnya?"

$P \quad:$ "coba lihat soal, informasi apa yang terdapat dalam soal itu yang bisa RO gunakan untuk menyelesaikan soal ini"

$R O$ :"Saya tidak tau bu"

$P \quad:$ :Kenapa kamu tidak bisa menulis yang diketahuinya?"

RO : "Saya tidak tau ini apa bu, dan tidak biasa menuliskan yang diketahui kalau mengerjakan soal"

Hasil wawancara yang dilakukan menunjukkan bahwa subjek RO bisa membaca dan mengetahui info apa yang ada dalam soal namun tidak bisa menuliskannya. Maka berdasarkan hasil tes dan wawancara, kesalahan ini disebabkan karena rendahnya rasa ingin tahu siswa dalam menyelesaikan soal dan tidak terbiasanya siswa dalam menuliskan hal yang diketahui sebelum menjawab soal.

\section{Kesalahan Pemahaman}

Kesalahan pemahaman yaitu siswa tidak mengetahui apa yang diketahui dan ditanyakan dalam soal. Dari hasil tes yang dilakukan terhadap siswa didapatlah bahwa sebanyak 41,78 \% siswa melakukan kesalahan pemahaman. Kesalahan ini merupakan kesalahan dengan persentase kedua terkecil dari total seluruh bentuk kesalahan. Gambar 2 berikut ini menunjukkan kesalahan pemahaman yang dilakukan oleh siswa 


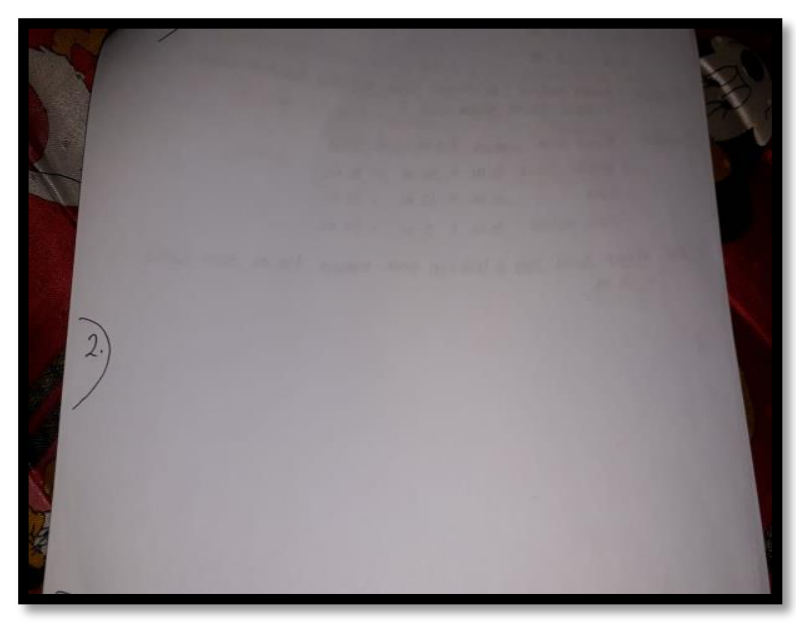

Gambar 1. Kesalahan Pemahaman Siswa

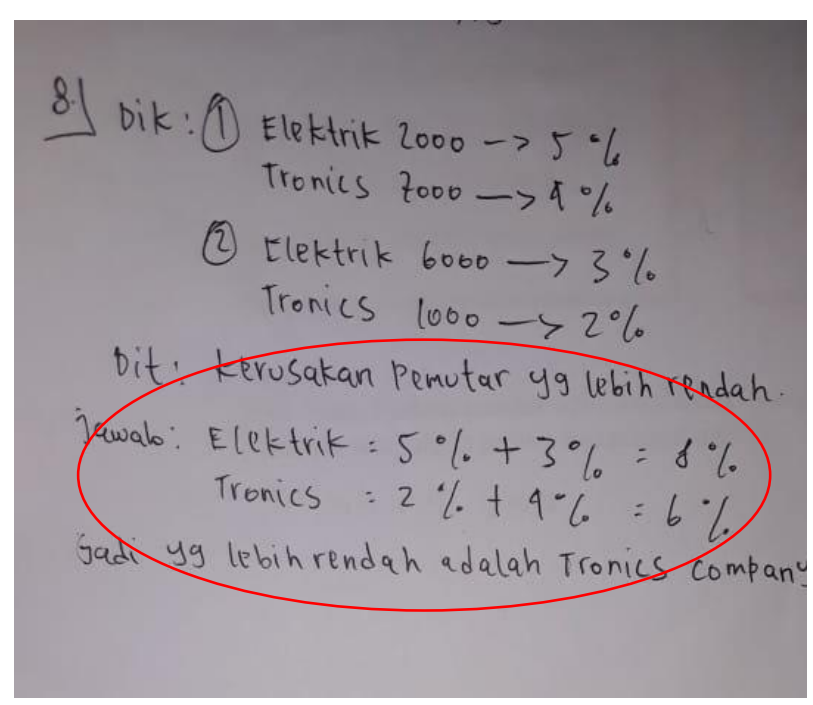

Gambar 2. Kesalahan Transformasi Siswa

Berdasarkan jawaban siswa pada Gambar 1 siswa tidak mengetahui dan tidak menuliskan apa yang diketahui dan ditanyakan dari soal. Berdasarkan hasil analisis tes dan wawancara, hal ini disebabkan oleh siswa yang kesulitan memahami soal serta kurang telitinya siswa dalam menafsirkan maksud dari soal. Sesuai dengan yang diungkapkan oleh Wati \& Murtiyasa (2016) bahwa rendahnya kemampuan berpikir siswa dalam menangkap informasi penting kemudian mengungkapkannya ke dalam strategi untuk pemecahan masalah menyebabkan kesalahan siswa dalam memahami masalah. Sejalan dengan hasil penelitian dari Shinariko, Hartono, \& Araiku (2020), penyebab lainnya yaitu siswa salah menangkap informasi yang terdapat dalam soal. Selain itu tidak terbiasanya siswa mengerjakan soal konteks nyata membuat siswa kesulitan memahami maksud dari soal. 


\section{Kesalahan Transformasi}

Kesalahan transformasi yaitu siswa mampu membaca pertanyaan dengan baik dan tahu apa yang ditanyakan dalam soal tetapi tidak dapat mengubah soal ke dalam bentuk matematika dengan tepat. Dari hasil analisis tes siswa, sebanyak 87,29 \% siswa melakukan kesalahan transformasi. Gambar 2 menunjukkan kesalahan transformasi yang dilakukan oleh siswa.

Dari hasil jawaban siswa pada Gambar 2 terlihat siswa belum mampu mengubah bentuk persen menjadi bentuk pecahan dengan kata lain siswa belum mampu mengubah soal menjadi bentuk matematika yang tepat. Berdasarkan hasil analisis data tes dan wawancara, kesalahan ini disebabkan oleh siswa sudah memahami permasalahan dalam soal namun tidak dapat menerjemahkannya kedalam bentuk matematika dengan tepat. Sesuai dengan hasil penelitian Shinariko, Hartono, \& Araiku (2020) bahwa kesalahan transformasi terjadi ketika siswa mampu memahami soal dari masalah yang diberikan tetapi siswa belum mampu mengubah soal ke dalam bentuk matematika dengan benar atau siswa gagal untuk memilih strategi matematika yang tepat untuk memecahkan masalah. Selain itu menurut Wati \& Murtiyasa (2016), siswa melakukan kesalahan dalam transformasi dikarenakan tidak terbiasa belajar sambil berfikir, sehingga siswa tidak mampu mengkaitkan informasi yang diperoleh ke dalam solusi yang tepat.

\section{Kesalahan Keterampilan Proses}

Kesalahan keterampilan proses yaitu siswa mampu membaca pertanyaan dengan baik dan paham apa yang diketahui dan apa yang ditanyakan dalam soal tetapi tidak akurat dalam proses menghitung. Selain itu juga kesalahan siswa yang hanya langsung menuliskan jawaban singkat (tidak tepat), tetapi ketika diwawancarai siswa dapat menjawab soal dengan tepat. Sebanyak 90,26\% siswa melakukan kesalahan keterampilan proses yang didapat dari hasil analisis data tes. Kesalahan ini merupakan jenis kesalahan dengan persentase yang terbesar.

Berdasarkan Gambar 3, hasil jawaban siswa menunjukkan bahwa siswa telah memahami maksud dari soal dan mengetahui rumus yang digunakan namun salah dalam perhitungan. Hal tersebut sesuai dengan hasil penelitian dari Shinariko, Hartono, \& Araiku (2020) bahwa kesalahan keterampilan proses terjadi ketika siswa telah mampu memilih operasi atau menentukan strategi diperlukan untuk menyelesaikan masalah tetapi tidak dapat menjalankan prosedur dengan benar atau mengalami kesalahan dalam proses perhitungan matematis. Setelah hasil tes tersebut dianalisis dan dilakukan wawancara didapatlah bahwa 
penyebab siswa melakukan kesalahan tersebut ialah dikarenakan terburu-burunya siswa dalam menyelesaikan soal dan lemahnya dalam proses perhitungan. Pendapat ini didukung oleh penelitian dari Wati \& Murtiyasa (2016) yaitu keterampilan hitung siswa yang lemah dalam menerapkan perhitungan ke dalam bentuk rumus/formula membuat siswa melakukan kesalahan dalam keterampilan proses. Selain itu tidak terbiasanya siswa menyelesaikan soal berkonteks nyata dan sulitnya siswa mengaitkan soal yang ada dalam PISA kedalam materi pembelajaran yang mereka pelajari biasanya juga menjadi penyebab siswa melakukan kesalahan keterampilan proses.

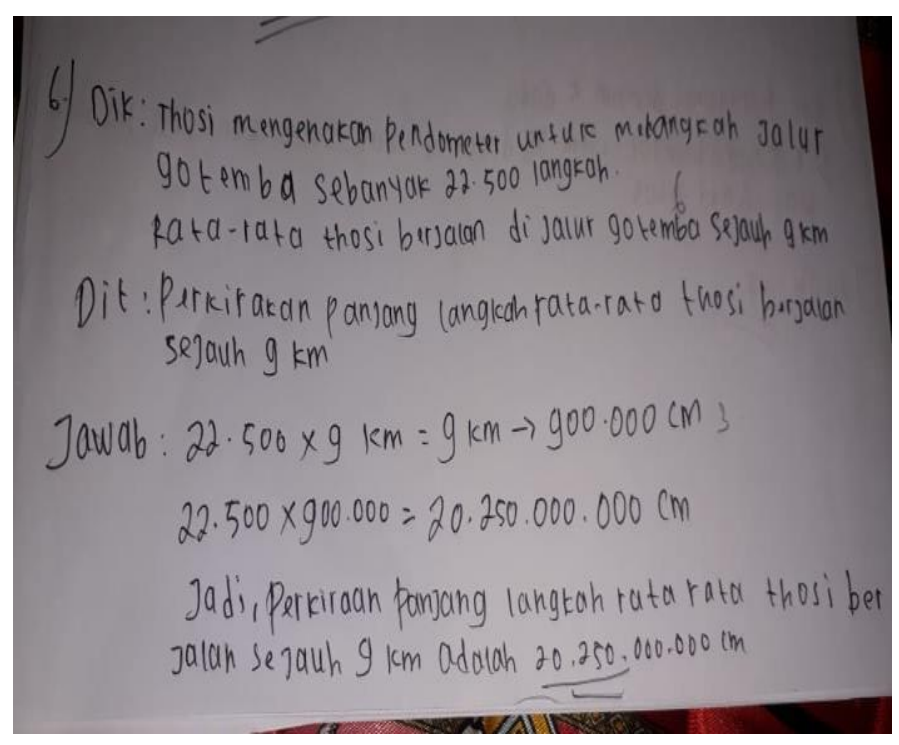

Gambar 3. Kesalahan Keterampilan Proses Siswa

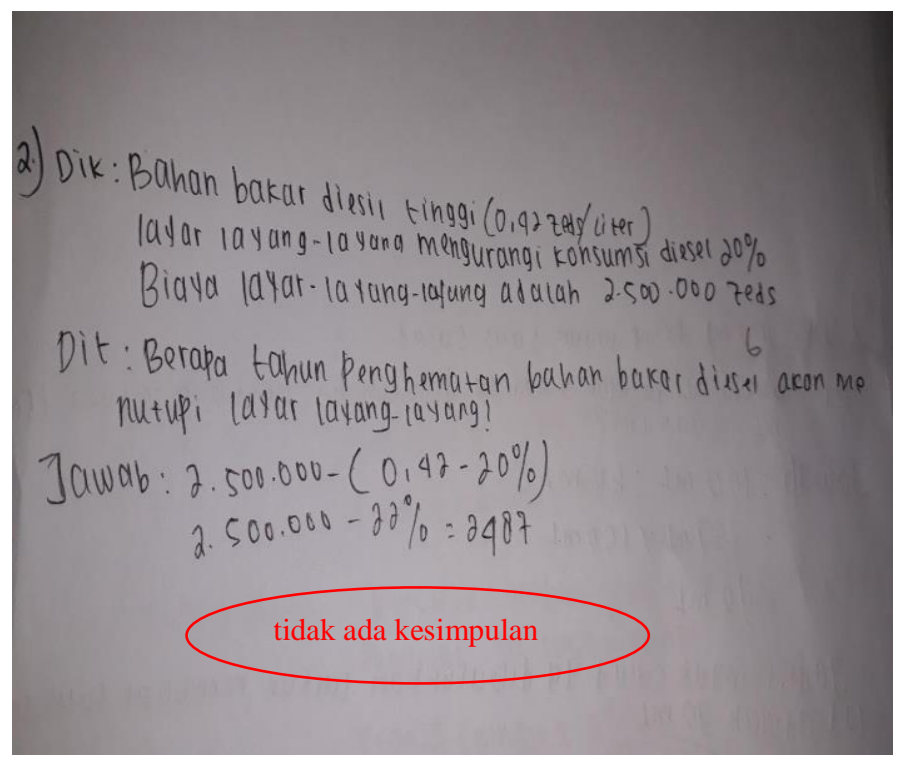

Gambar 4. Kesalahan Penulisan Jawaban Siswa 


\section{Kesalahan Penulisan Jawaban}

Kesalahan penulisan jawaban yaitu kesalahan siswa dalam menuliskan jawaban akhir. Tidak menuliskan kesimpulan diakhir jawaban biasanya merupakan bentuk kesalahan yang sering dilakukan siswa dalam kesalahan penulisan jawaban. Dari hasil analisis data tes, sebanyak 88,46 \% siswa melakukan kesalahan penulisan jawaban. Gambar 4 diatas menunjukkan kesalahan penulisan jawaban siswa yaitu tidak menuliskan kesimpulan diakhir jawaban. Penyebab siswa melakukan kesalahan tersebut ialah siswa teah mengalami kesalahan dalam tahap sebelumnya sehingga siswa tidak bisa menyelesaikan jawabannya dengan sempurna. Hal ini sejalan dengan penelitian yang dilakukan oleh Nisa \& Rejeki (2017), bahwa siswa tidak biasa dalam melakukan proses memeriksa kembali jawaban yang sudah diperoleh menjadi salah satu penyebab siswa melakukan kesalahan dalam penulisan jawaban.

\section{SIMPULAN}

Dari penjelasan tentang penelitian ini, dapat disimpulkan bahwa: (1) Berdasarkan hasil analisis data tes dan wawancara, terdapat 5 bentuk kesalahan yang dilakukan siswa dalam menyelesaikan soal matematika tipe PISA di Sekolah Menengah Pertama (SMP) yang dianalisis menggunakan metode Newman yaitu kesalahan membaca sebesar $40.21 \%$, kesalahan pemahaman sebesar 41.78\%, kesalahan transformasi sebesar 87.29\%, kesalahan keterampilan proses sebesar $90.26 \%$ dan kesalahan penulisan jawaban sebesar $88.46 \%$. Maka kesimpulannya kesalahan yang paling banyak dilakukan oleh siswa adalah kesalahan keterampilan proses yaitu dengan persentase sebesar 90.26\%. (2) Adapun faktor yang menyebabkan siswa melakukan kesalahan tersebut adalah : (a) Kesalahan membaca, rendahnya rasa ingin tahu siswa dalam menyelesaikan soal dan tidak terbiasanya siswa dalam menuliskan hal yang diketahui sebelum menjawab soal adalah faktor penyebab siswa melakukan kesalahan membaca, (b) Kesalahan pemahaman, kesulitan memahami soal, kurrag telitinya siswa dalam menafsirkan maksud dari soal, rendahnya kemampuan berpikir siswa, siswa salah menangkap informasi yang terdapat dalam soal dan tidak terbiasanya siswa mengerjakan soal konteks nyata membuat siswa kesulitan memahami maksud dari soal, (c) Kesalahan transformasi, siswa tidak dapat menerjemahkan soal kedalam bentuk/model matematika yang tepat, siswa gagal memiih strategi matematika yang tepat, siswa tidak terbiasa belajar sambil berfikir sehingga siswa tidak mampu mengkaitkan informasi yang diperoleh ke dalam solusi yang tepat menjadi penyebab kesalahan transformasi siswa, (d) Kesalahan keterampilan proses, terburu-burunya siswa dalam menyelesaikan soal, lemahnya 
keterampilan menghitung siswa, tidak terbiasanya siswa menyelesaikan soal berkonteks nyata serta sulitnya siswa mengaitkan soal yang ada dalam PISA kedalam materi pembelajaran menjadi penyebab siswa melakukan kesalahan ini, dan (e) Kesalahan penulisan jawaban, mengalami kesalahan pada tahap sebelumnya, tidak dapat menyelesaikan jawaban dengan sempurna serta siswa tidak biasa melakukan proses memeriksa kembali jawaban yang sudah diperoleh menjadi salah satu penyebab siswa melakukan kesalahan dalam penulisan jawaban.

Dengan adanya penelitian ini diharapkan agar kedepannya untuk guru ketika akan mengajarkan materi yang berkaitan dengan soal PISA seperti materi aljabar, geometri, bilangan dan statistika agar lebih membiasakan diri untuk memberikan soal berkonteks nyata kepada siswa dalam proses pembelajaran dikelas, mengingatkan siswa untuk tidak terburuburu ketika menyelesaikan soal, serta mengingatkan siswa untuk melakukan proses menghitung dan prosedur yang benar dalam menyelesaikan soal yang berkaitan dengan materi tersebut. Sedangkan untuk siswa agar dapat menyelesaikan soal PISA dengan baik maka siswa harus terbiasa mengerjakan soal-soal berkonteks nyata, melakukan pengerjaan soal dengan prosedur yang benar, lebih teliti lagi dan dibiasakan untuk memeriksa kembali proses penyelesaiannya sebelum menuliskan jawaban akhir dari penyelesaian soal.

\section{REFERENSI}

Astuty, K. Y., \& Wijayanti, P. (2013). Analisis Kesalahan Siswa Kelas V Dalam Menyelesaikan Soal Matematika Pada Materi Pecahan di SDN Medokan Semampir 1/259 Surabaya. MATHEdunesia, 3(2), 1-7.

Clements, M. K. (1980). Analyzing children's errors on written mathematical tasks. Educational studies in mathematics, 11(1), 1-21.

Fatimah, F. Y. N. (2018). Analisis Kesalahan Mengerjakan Soal Matematika Materi Pecahan Dengan Teori Newman. As-Sibyan, 1(2), 17-31.

Mahmudah, W. (2018). Analisis kesalahan siswa dalam menyelesaikan soal matematika bertipe Hots berdasar Teori Newman. Jurnal UJMC, 4(1), 49-56.

Nisa, M. K., \& Rejeki, S. (2017). Analisis Kesalahan Siswa Kelas VII Dalam Memecahkan Soal Matematika Model PISA Konten Quantity. Seminar Nasional Pendidikan Matematika. Universitas Muhammadiyah Surakarta.

OECD. (2019). Combined Executive Summaries PISA 2018 Result. Paris: OECD Publishing.

OECD. (2019). PISA 2018 Global Competence Framework. Paris: OECD Publishing.

Putra, F. A. (2018). Analisis Kemampuan Literasi Matematika Siswa SMP Melalui Penyelesaian Soal PISA (Doctoral dissertation, University of Muhammadiyah Malang). 
Putri, A. M., \& Mega, T. B. (2017). Analisis Kesalahan Siswa Smp Dalam Menyelesaikan Soal Cerita Matematika Berdasarkan Tahapan Newman Serta Upaya Untuk Mengatasinya Menggunakan Scaffolding. Mathedunesa Jurnal Ilmiah Pendidikan Matematika, 2(6), 277-284.

Shinariko, L. J., Saputri, N. W., Hartono, Y., \& Araiku, J. (2020). Analysis of students' mistakes in solving mathematics olympiad problems. Journal of Physics: Conference Series, $1480(1), 012039$.

Siswandi, E., Sujadi, I., \& Riyadi, R. (2016). Analisis Kesalahan Siswa Dalam Menyelesaikan Masalah Matematika Kontekstual pada Materi Segiempat Berdasarkan Analisis Newman Ditinjau dari Perbedaan Gender (Studi Kasus pada Siswa Kelas VII SMPN 20 Surakarta). Jurnal Pembelajaran Matematika, 4(7), 633-643.

Sugiyono. (2015). Metode Penelitian Pendidikan (Pendekatan Kuantitatif, Kualitatif, dan $R \& D)$. Bandung: Alfabeta.

Susilowati, P. L., \& Ratu, N. (2018). Analisis Kesalahan Siswa Berdasarkan Tahapan Newman Dan Scaffolding Pada Materi Aritmatika Sosial. Mosharafa: Jurnal Pendidikan Matematika, 7(1), 13-24.

Umam, M. D. (2014). Analisis Kesalahn Siswa Dalam Menyelesaikan Soal Cerita Matematika Materi Operasi Hitung Pecahan . MATHEdunesa , 4(7), 633-643.

Utami, A. S. (2018). Analisis kesalahan siswa dalam menyelesaikan soal cerita pokok bahasan komposisi fungsi di SMK Bakti Purwokerto. AlphaMath: Journal of Mathematics Education, 3(2), 48-56.

Wati, E. H., \& Murtiyasa, B. (2016). Kesalahan Siswa SMP Dalam Menyelesaikan Soal Matematika Berbais PISA Pada Konten Change And Relationship. Konferensi Nasional Penelitian Matematika dan Pembelajarannya (KNPMP I). Surakarta. 